\title{
MODEL REGRESI LOGISTIK MULTINOMIAL UNTUK MENENTUKAN PILIHAN SEKOLAH LANJUTAN TINGKAT ATAS PADA SISWA SMP
}

\author{
Puji Subekti \\ Mahasiswa Program Magister Matematika Universitas Brawijaya Malang \\ Telp : 085649603425; Email : ukhti_ajieb88@yahoo.com
}

\begin{abstract}
In general, secondary schools in Indonesia contained three institutions namely SMA (Senior High School), SMK (vocational high school) and MA (Madrasah Aliyah). This study to determine the variables that significantly influence, so we can know the probability of students in choosing junior high school after study. The analysis tool used is the multinomial logistic regression analysis. At the $95 \%$ confidence level is obtained that out of 8 (eight) independent variables are used, there are 5 (five) variables that significantly influence. They are the father's education, mother's education, mother's income, number of siblings, and father's occupation.
\end{abstract}

Keywords: multinomial logistic regression analyzes, SMA, MA, SMK, Probability selection school.

\begin{abstract}
ABSTRAK
Secara umum, sekolah menengah di Indonesia terdapat tiga lembaga yakni SMA (SMA), SMK (Sekolah Menengah Kejuruan) dan MA (Madrasah Aliyah). Penelitian ini untuk mengetahui variabel yang mempengaruhi secara signifikan, sehingga kita dapat mengetahui kemungkinan siswa dalam memilih SMP setelah alat analisis study.The digunakan adalah analisis regresi logistik multinomial. Pada tingkat kepercayaan 95\% diperoleh bahwa dari 8 (delapan) variabel independen yang digunakan, ada 5 (lima) variabel yang mempengaruhi secara signifikan.Salah satu diantaranya adalah pendidikan ayah, pendidikan ibu, pendapatan ibu, jumlah saudara kandung, dan pekerjaan ayah.
\end{abstract}

Keywords: multinomial logistic regression analyzes, SMA, MA, SMK, Probability selection school.

\section{PENDAHULUAN}

Pada umumnya, sekolah menengah di Indonesia diwadahi tiga lembaga yakni SMA, SMK dan MA. SMA bertujuan untuk menyediakan dan menyiapkan siswa/i yang hendak melanjutkan studi ke jenjang yang lebih tinggi, akademi atau perguruan tinggi, sedangkan SMK lebih ditujukan untuk menyediakan tenaga kerja tingkat menengah. MA, sebagaimana SMA bertujuan untuk mengantarkan siswa memasuki perguruan tinggi umum maupun perguruan tinggi Islam. Kenyataannya tidak semua lulusan SMA berkesempatan melanjutkan studi ke jenjang yang lebih tinggi karena berbagai alasan, begitu pula dengan lulusan SMK dan MA [1].

Beberapa faktor yang diduga mempengaruhi siswa dalam memilih sekolah lanjutan adalah umur siswa, jenis kelamin siswa, asal sekolah siswa, nilai rata-rata mapel siswa pada semester 1, jumlah tanggungan anak dalam keluarga yang masih bersekolah, pendidikan orangtua siswa, pekerjaan orangtua siswa, penghasilan orangtua siswa, minat, dan dukungan keluarga. Faktor-faktor tersebut akan diduga mempengaruhi siswa dalam memilih sekolah lanjutan sehingga disebut sebagai variabel independen. Sedangkan sekolah lanjutan yaitu: SMA, SMK, dan MA disebut sebagai variabel terikat. Sehubungan dengan hal tersebut untuk menganalisis hubungan antara variabel terikat yang mempunyai kategori lebih dari dua, dengan beberapa variabel independen yang bersifat kontinu, kategorik, atau keduanya adalah dengan menggunakan analisis regresi logistik multinomial.

\section{KAJIAN TEORI}

\section{Model}

Model adalah pola (contoh, acuan, ragam) dari sesuatu yang akan dibuat atau dihasilkan. Definisi lain dari model adalah abstraksi dari sistem sebenarnya, dalam 
gambaran yang lebih sederhana serta mempunyai tingkat prosentase yang bersifat menyeluruh, atau model adalah abstraksi dari realitas dengan hanya memusatkan perhatian pada beberapa sifat dari kehidupan sebenarnya. Model yang akan disusun dalam penelitian ini termasuk model simbolis, yaitu model yang menggambarkan sistem yang ditinjau dengan simbol-simbol biasanya dengan simbol-simbol matematik. Dalam hal ini sistem diwakili oleh variabel-variabel dari karakteristik sistem yang ditinjau.

\section{Regresi Logistik}

Regresi logistik merupakan salah satu metode yang dapat digunakan untuk mencari hubungan varia-bel respon yang bersifat dichotomous (berskala nominal atau ordinal dengan dua kategori) atau polychotomous (mempunyai skala nominal atau ordinal dengan lebih dari dua kategori) dengan satu atau lebih variabel prediktor dan variabel respon bersifat kontinyu atau kategorik [2].

\section{Regresi Logistik Multinomial}

Regresi logistik multinomial merupakan regresi logistik yang digunakan saat variabel dependen mempunyai skala yang bersifat polichotomous atau multinomial. Metode yang digunakan dalam penelitian ini adalah regresi logistik dengan variabel respon berskala nominal dengan tiga kategori. Model yang digunakan pada regresi logistik multinomial adalah

$$
\operatorname{Logit} P(Y=1)=\propto+\beta_{1} X_{1}+\beta_{2} X_{2}+\ldots+
$$
$\beta_{n} X_{n}$

Dengan menggunakan transformasi logit didapatkan fungsi logit,

$$
\begin{aligned}
P_{1}(x) & =\ln \left[\frac{P(Y=1) 1 \mid x}{P(Y=1) 0 \mid x}\right] \\
& =\beta_{10}+\beta_{11} X_{1}+\beta_{12} X_{2}+\ldots+\beta_{1 n} X_{n} \\
& =x^{\prime} \beta_{1} \\
P_{2}(x) & =\ln \left[\frac{P(Y=1) 2 \mid x}{P(Y=1) 0 \mid x}\right] \\
& =\beta_{20}+\beta_{21} X_{1}+\beta_{22} X_{2}+\ldots \\
& \quad+\beta_{2 n} X_{n}=x^{\prime} \beta_{2}
\end{aligned}
$$

Berdasarkan kedua fungsi logit tersebut maka didapatkan model regresi logistik trichotomous sebagai berikut:

$$
\pi_{0}(\text { 目 })=\frac{1}{1+\exp P_{1}(x)+\exp P_{2}(x)}
$$

$$
\begin{aligned}
& \pi_{1}(x)=\frac{\exp P_{1}(x)}{1+\exp P_{1}(x)+\exp P_{2}(x)} \\
& \pi_{2}(x)=\frac{\exp P_{2}(x)}{1+\exp P_{1}(x)+\exp P_{2}(x)}
\end{aligned}
$$

Untuk menguji signifikansi $\beta$ dari model yang telah diperoleh, maka dilakukan uji parsial dan uji serentak.

\section{A. Uji parsial}

Pengujian signifikansi parameter menggunakan uji Wald [3] dengan hipothesis di bawah ini :

$$
\begin{aligned}
& H_{-} 0: \beta_{-} k=0, \text { dengan } h=1,2,3, \ldots k \\
& H_{-} 1: \beta_{-} k \neq 0, \text { dengan } h=1,2,3, \ldots k
\end{aligned}
$$

Perhitungan statistik uji Wald adalah sebagai berikut :

$$
\text { wald }=\frac{\hat{\beta}_{k}}{S E\left(\widehat{\hat{\beta}_{k}}\right)}
$$

\section{B. Uji Serentak}

Hipotesis untuk pengujian adalah sebagai berikut:

$\mathrm{H}_{0} \quad: \beta_{1}=\beta_{2}=\cdots=\beta_{p}=0$

$\mathrm{H}_{1} \quad$ : Paling tidak ada satu $\beta_{i}$ yang tidak sama dengan 0 di mana $i=$ $1,2, \ldots, n$ (n adalah banyaknya lokasi pengamatan) dan $k=1,2, \ldots, p$ (p adalah banyaknya variabel prediktor).

statistik uji $G^{2}$ atau likelihood ratio test yang dinyatakan sebagai berikut:

$$
G^{2}=-2 \ln \left(\frac{L(\widehat{\omega})}{L(\hat{\Omega})}\right)
$$

Menurut Hosmer dan Lemeshow (1989), statistik uji $G^{2}$ mengikuti distribusi chi-square, sehingga untuk memperoleh keputusan dilakukan perbandingan dengan titik kritis $\chi_{(\alpha, d b)}^{2}$ di mana derajat bebasnya adalah $\mathrm{p}$ atau banyaknya variabel prediktor. Kriteria penolakan (tolak $\mathrm{H}_{0}$ ) jika nilai $G^{2}>$ $\chi_{(\alpha, d b)}^{2}$.

\section{Uji Kesesuaian Model}

Uji kesesuaian model dengan menggunakan statistik uji Chi-square adalah sebagai berikut

$$
X^{2}=\sum_{k=1}^{g} \frac{\left(O_{k}-n^{\prime}{ }_{k} \bar{\pi}_{k}\right)^{2}}{n_{k}{ }_{k} \bar{\pi}_{k}\left(1-\bar{\pi}_{k}\right)}
$$


Statistik uji di atas untuk menguji hipotesis sebagai berikut :

$H_{0}$ : Model sesuai (Tidak ada perbedaan yang nyata antara hasil observasi dengan kemungkinan hasil prediksi model)

$H_{1}$ : Model tidak sesuai (ada perbedaan yang nyata antara hasil observasi dengan kemungkinan hasil prediksi model).

Pengambilan keputusan didasarkan pada tolak $H_{0}$ jika $X_{\text {hitung }}^{2} \geq X^{2}{ }_{(d b, \propto)}$ dengan $\mathrm{db}=\mathrm{g}-2$.

\section{Pendidikan SMA, MA dan SMK}

Menurut Salim (2008) Sistem pendidikan di Indonesia secara umum masih dititikberatkan pada kecerdasan kognitif. Hal ini dapat dilihat dari orientasi sekolah sekolah yang ada masih disibukkan dengan ujian, mulai dari ujian mid, ujian akhir hingga ujian nasional. Ditambah latihan-latihan soal harian dan pekerjaan rumah untuk memecahkan pertanyaan di buku pelajaran yang biasanya tidak relevan dengan kehidupan sehari hari para siswa.

Setelah jenjang pendidikan menengah pertama, ada beberapa jenis tingkat sekolah diantaranya SMA, MA, SMK, SMEA dan lainlain. Masing-masing diantara sekolah tersebut berbeda dalam penyusunan kurikulumnya menurut visi dan misi masingmasing. Sebagian diantara mereka ada yang lebih menekankan teori dan sebagian lagi lebih mengedepankan praktik. Namun tidak perlu mempermasalahkan tentang hal itu, semakin beragam pendidikan di negara kita akan semakin mudah untuk membentuk sumberdaya alam yang sangat bermutu.

Diantara ciri-ciri kurikulum SMA maupun MA adalah sebagai berikut:

1. Materi pembelajaran lebih mengarah kepada teori dari pada praktik.

2. Tamatannya tidak siap kerja.

3. Tempat belajar lebih tertuju di sekolah.

Ciri-ciri kurikulum SMK, diantaranya:

1. Materi pembelajaran lebih mengarah kepada praktek dari pada teori, dapat dikatan 60\% paraktek dan $40 \%$ teori.

2. Tamatannya siap kerja

3. Tempat belajar di sekolah dan di dunia kerja.

\section{METODE PENELITIAN}

Rancangan penelitian yang pertama dilakukan pada siswa secara langsung dengan pengisian kuisioner mengenai faktorfaktor internal yang mempengaruhi siswa dalam pemilihan kelanjutan pendidikan setelah lulus dari SMP.

Adapun variabel - variabel dependen dan variabel - variabel independen yang dipergunakan dalam penelitian ini diantaranya adalah :

1. Y sebagai variabel dependen yang terdiri atas tiga kategori yaitu Sekolah SMA (dengan kode 0), MA (dengan kode 1), dan SMK (dengan kode 2).

2. X sebagai variabel independen yang terdiri atas 8 variabel yaitu pendidikan ibu (X1), pendidikan ayah(X2) ,penghasilan ibu(X3), penghasilan ayah(X4), jumlah saudara(X5), jumlah tanggungan keluarga (X6) pekerjaan ayah(X7), nilai rata-rata matapelajaran yang diikutkan dalam UAN(X8).

Dalam penelitian ini dipilih siswasiswi SMP Negeri 2 Malang kelas VIII sebagai sampel penelitian sebab sebagaimana khalayak umum ketehui bahwa SMP Negeri 2 Malang merupakan salah satu SMP yang dianggap oleh masyarakat sebagai SMP yang dapat memberikan keluaran siswa-siswi berprestasi khususnya dibidang akademik,

Langkah-langkah analisis data dalam penelitian ini adalah sebagai berikut :

1. Melakukan uji validitas terhadap itemitem soal.

2. Melakukan uji reliabilitas terhadap itemitem soal. Jika item-item soal telah memenuhi uji validitas dan reabilitas maka dapat dilakukan pada pengujian selanjutnya.

3. Melakukan analisis regresi logistik terhadap data:

4. Menaksir parameter yang diperoleh.

5. Menginterpretasikan model regresi logistik.

6. Melakukan Uji Serentak, parsial dan kesesuaian model

7. Evaluasi model 


\section{HASIL DAN PEMBAHASAN}

\section{Karakteristik Siswa SMP Negeri 2 Malang}

Siswa SMP Negeri 2 Malang yang dijadikan sebagai obyek penilitian seperti dijelaskan sebelumnya berjumlah 108 siswa. Ditinjau dari segi pendidikan terakhir ibu $18,5 \%$ berpendidikan SD, 23,1\% berpendidikan SMP, 44,4\% berpendidikan SMA, dan 13,9\% berpendidikan Sarjana. Dari segi pendidikan terakhir ayah juga terdapat $18,5 \%$ berpendidikan SD, 20,4\% berpendidikan SMP, 47,2\% berpendidikan SMA, dan 13,9\% berpendidikan Sarjana. Jika ditinjau dari penghasilan ibu yang kurang dari 700.000 sebanyak 72\%,sebanyak 19,4\% antara 700.00 sampai 2.000 .000 dan $8,3 \%$ diatas 2.000.000. ditinjau dari penghasilan ayah yang kurang dari 700.000 sebanyak $46,3 \%$,sebanyak $29,6 \%$ antara 700.00 sampai 2.000 .000 dan $824,1 \%$ diatas 2.000.000. keluarga siswa yang tidak mempunyai saudara sebanyak 10,2\%. Sebanyak 19,4\% mempunyai 1 saudara, 52,8\% mempunyai 2 saudara, 7,4\% mempunyai 3 saudara dan $10,2 \%$ mempunyai lebih dari 3 saudara. keluarga siswa yang tidak mempunyai tanggungan sebanyak 1,9\%. Sebanyak 32,4\% mempunyai 1 tanggungan, $48,1 \%$ mempunyai 2 tanggungan, $13 \%$ mempunyai 3 tanggungan dan 4,6\% mempunyai lebih dari 3 tanggungan keluarga. Ditinjau dari jenis pekerjaan ayah $13,9 \%$ seorang PNS, 12,0\% Wiraswasta, 59,3\% karyawan swasta, dan 14,8\% lain-lain. Sedangkan siswa yang mempunyai nilai diatas 75 sebanyak $65,7 \%$ dan 33,3\% dibawah 75 .

\section{Regresi Logistik Multinomial secara Individu}

Untuk mengetahui pengaruh dari faktor-faktor yang diduga mempengaruhi pemilihan sekolah lanjutan tingkat atas pada siswa SMP secara individu, dilakukan uji Wald dan p-value disajikan dalam tabel berikut ini :

Tabel 1 Regresi Logistik Multinomial Secara Individu

\begin{tabular}{|c|c|c|c|c|c|}
\hline Logit & Variabel & B & Wald & P-value & $\operatorname{Exp}(B)$ \\
\hline \multirow{2}{*}{$\begin{array}{l}\text { Pendidikan Ibu } \\
\text { SMA / MA }\end{array}$} & Konstanta & 1,099 & 2,716 & 0,099 & 0 \\
\hline & $\begin{array}{l}\text { SD } \\
\text { SMP } \\
\text { SMA } \\
\text { SARJANA }\end{array}$ & $\begin{array}{l}-3,871 \\
-2,351 \\
-2,135 \\
0\end{array}$ & $\begin{array}{l}9,945 \\
7,219 \\
8,028 \\
0\end{array}$ & $\begin{array}{l}0,002^{*} \\
0,007^{*} \\
0,005^{*} \\
0\end{array}$ & $\begin{array}{l}0,021 \\
0,095 \\
0,118 \\
0\end{array}$ \\
\hline SMK & $\begin{array}{l}\text { Konstanta } \\
\text { SD } \\
\text { SMP } \\
\text { SMA } \\
\text { SARJANA }\end{array}$ & $\begin{array}{r}-0,405 \\
-2,367 \\
-0.847 \\
-2.335 \\
0\end{array}$ & $\begin{array}{l}0,197 \\
2,956 \\
0,622 \\
3,994 \\
0\end{array}$ & $\begin{array}{l}0,657 \\
0,086 \\
0,430 \\
0,046^{*} \\
0\end{array}$ & $\begin{array}{l}0 \\
0,094 \\
0,429 \\
0,097 \\
0\end{array}$ \\
\hline $\begin{array}{l}\text { Pendidikan Ayah } \\
\text { SMA/MA }\end{array}$ & $\begin{array}{l}\text { Konstanta } \\
\text { Pend.Ayah SD } \\
\text { SMP } \\
\text { SMA } \\
\text { SARJANA }\end{array}$ & $\begin{array}{l}1,504 \\
-4,212 \\
-3,701 \\
-2,306 \\
0\end{array}$ & $\begin{array}{l}3,702 \\
10.575 \\
11,743 \\
7,363 \\
0\end{array}$ & $\begin{array}{l}0,054 \\
0,001^{*} \\
0,001^{*} \\
0,017^{*} \\
0\end{array}$ & $\begin{array}{l}0 \\
0,015 \\
0,025 \\
0,100 \\
0\end{array}$ \\
\hline SMK & $\begin{array}{l}\text { Konstanta } \\
\text { Pend.Ayah SD } \\
\text { SMP } \\
\text { SMA } \\
\text { SARJANA }\end{array}$ & $\begin{array}{r}-1,386 \\
-0,754 \\
-0,811 \\
-0,256 \\
0 \\
\end{array}$ & $\begin{array}{l}1,537 \\
0,314 \\
0,364 \\
0,045 \\
0\end{array}$ & $\begin{array}{l}0,215 \\
0,575 \\
0,546 \\
0,832 \\
0\end{array}$ & $\begin{array}{l}0 \\
0,471 \\
0,444 \\
0,774 \\
0 \\
\end{array}$ \\
\hline $\begin{array}{l}\text { Penghasilan Ayah } \\
\text { SMA }\end{array}$ & $\begin{array}{l}\text { Konstanta } \\
<700 \\
700<x<2.000 \\
>2.000\end{array}$ & $\begin{array}{r}1,041 \\
-4,037 \\
-2,140 \\
0\end{array}$ & $\begin{array}{l}4,810 \\
21,718 \\
10,230 \\
0\end{array}$ & $\begin{array}{l}0,028 \\
0,000^{*} \\
0,001^{*} \\
0\end{array}$ & $\begin{array}{l}0 \\
0,018 \\
0,118 \\
0\end{array}$ \\
\hline SMK & $\begin{array}{l}\text { Konstanta } \\
<700 \\
700<\mathrm{x}<2.000 \\
>2.000\end{array}$ & $\begin{array}{l}-1,792 \\
-0,799 \\
0,511 \\
0\end{array}$ & $\begin{array}{l}2,752 \\
0,418 \\
0,183 \\
0\end{array}$ & $\begin{array}{l}0,097 \\
0,518 \\
0,668 \\
0\end{array}$ & $\begin{array}{l}0 \\
0 \\
0,450 \\
1,667\end{array}$ \\
\hline
\end{tabular}




\begin{tabular}{|c|c|c|c|c|c|}
\hline $\begin{array}{l}\text { Penghasilan Ibu } \\
\text { SMA }\end{array}$ & $\begin{array}{l}\text { Konstanta } \\
<700 \\
700<x<2.000 \\
>2.000\end{array}$ & $\begin{array}{l}0,693 \\
-2,266 \\
-0,693 \\
0\end{array}$ & $\begin{array}{l}0,961 \\
8,417 \\
0,641 \\
0\end{array}$ & $\begin{array}{l}0,327 \\
0,004^{*} \\
0,423 \\
0\end{array}$ & $\begin{array}{l}0 \\
0,104 \\
0,500 \\
0\end{array}$ \\
\hline SMK & $\begin{array}{l}\text { Konstanta } \\
<700 \\
700<x<2.000 \\
>2.000\end{array}$ & $\begin{array}{l}-19,868 \\
17,844 \\
18,482 \\
0 \\
\end{array}$ & $\begin{array}{l}631,604 \\
404,726 \\
0 \\
0 \\
\end{array}$ & $\begin{array}{l}0,000^{*} \\
0,000^{*} \\
0,000^{*} \\
0,000^{*}\end{array}$ & $\begin{array}{l}0 \\
5,618 \mathrm{E} 7 \\
1,063 \mathrm{E} 8 \\
0\end{array}$ \\
\hline $\begin{array}{l}\text { Jumlah Saudara } \\
\text { SMA }\end{array}$ & $\begin{array}{l}\text { Konstanta } \\
=0 \\
=1 \\
=2 \\
=3 \\
>3\end{array}$ & $\begin{array}{l}-0,981 \\
0,288 \\
-0,272 \\
0,288 \\
-19,419 \\
0\end{array}$ & $\begin{array}{l}2,099 \\
0.086 \\
0,095 \\
0,148 \\
0 \\
0\end{array}$ & $\begin{array}{l}0,147 \\
0,769 \\
0,758 \\
0,700 \\
0 \\
0\end{array}$ & $\begin{array}{l}0 \\
1,333 \\
0,762 \\
1,333 \\
3,686 \mathrm{E}-9 \\
0\end{array}$ \\
\hline SMK & $\begin{array}{l}\text { Konstanta } \\
=0 \\
=1 \\
=2 \\
=3 \\
>3\end{array}$ & $\begin{array}{l}-21,127 \\
19,335 \\
19,586 \\
19,112 \\
19,335 \\
0\end{array}$ & $\begin{array}{l}382,576 \\
160,217 \\
244,123 \\
251,905 \\
0 \\
0\end{array}$ & $\begin{array}{l}0,000^{*} \\
0,000^{*} \\
0,000^{*} \\
0,000^{*} \\
0,000^{*} \\
0,000^{*}\end{array}$ & $\begin{array}{l}0 \\
1,250 \mathrm{E} 7 \\
2,749 \mathrm{E} 7 \\
1,884 \mathrm{E} 7 \\
2,495 \mathrm{E} 8 \\
0\end{array}$ \\
\hline $\begin{array}{l}\text { Jumlah } \\
\text { Tanggungan } \\
\text { SMA }\end{array}$ & $\begin{array}{l}\text { Konstanta } \\
=0 \\
=1 \\
=2 \\
=3 \\
>3\end{array}$ & $\begin{array}{l}-1.386 \\
1,386 \\
0,197 \\
0,584 \\
0,539 \\
0\end{array}$ & $\begin{array}{l}1,537 \\
0,591 \\
0,027 \\
0,250 \\
0,168 \\
0\end{array}$ & $\begin{array}{l}0,215 \\
0,442 \\
0,870 \\
0,617 \\
0,682 \\
0\end{array}$ & $\begin{array}{l}0 \\
4,000 \\
1,217 \\
1,793 \\
1,714 \\
0\end{array}$ \\
\hline SMK & $\begin{array}{l}\text { Konstanta } \\
=0 \\
=1 \\
=2 \\
=3 \\
>3\end{array}$ & $\begin{array}{l}-19,239 \\
0,324 \\
16,797 \\
17,481 \\
17,986 \\
0\end{array}$ & $\begin{array}{l}0,0000 \\
0,0000 \\
0,0000 \\
0,0000 \\
0,0000 \\
0,0000\end{array}$ & $\begin{array}{l}0,998 \\
0,000^{*} \\
0,998 \\
0,998 \\
0,998 \\
0\end{array}$ & $\begin{array}{l}0 \\
1,382 \\
1,971 \mathrm{E} 7 \\
3,909 \mathrm{E} 7 \\
6,478 \mathrm{E} 7 \\
0\end{array}$ \\
\hline $\begin{array}{l}\text { Pekerjaan Ayah } \\
\text { SMA }\end{array}$ & $\begin{array}{l}\text { Konstanta } \\
\text { Lain-lain } \\
\text { Swasta } \\
\text { Wiraswasta } \\
\text { PNS }\end{array}$ & $\begin{array}{l}1,609 \\
-4,094 \\
-2,886 \\
-2,862 \\
0\end{array}$ & $\begin{array}{l}, 317 \\
9,959 \\
11,785 \\
6,591 \\
0 \\
\end{array}$ & $\begin{array}{l}0,038 \\
0,002^{*} \\
0,001^{*} \\
0,010^{*} \\
0,000^{*}\end{array}$ & $\begin{array}{l}0 \\
0,017 \\
0,056 \\
0,057 \\
0 \\
\end{array}$ \\
\hline SMK & $\begin{array}{l}\text { Konstanta } \\
\text { Lain-lain } \\
\text { Swasta } \\
\text { Wiraswasta } \\
\text { PNS }\end{array}$ & $\begin{array}{l}0,000 \\
-1,386 \\
-2,663 \\
-1,946 \\
0 \\
\end{array}$ & $\begin{array}{l}0,000 \\
1,357 \\
5,226 \\
1,767 \\
0 \\
\end{array}$ & $\begin{array}{l}1,000 \\
0,244 \\
0,002^{*} \\
0,184 \\
0\end{array}$ & $\begin{array}{l}0 \\
0,250 \\
0,070 \\
0,143 \\
0 \\
\end{array}$ \\
\hline Nilai & $\begin{array}{l}\text { Konstanta } \\
<75 \\
>75\end{array}$ & $\begin{array}{l}-1,962 \\
-0,523 \\
0,219\end{array}$ & $\begin{array}{l}22,925 \\
0,386 \\
0\end{array}$ & $\begin{array}{l}0,000 \\
0,534 \\
0,000^{*}\end{array}$ & $\begin{array}{l}0 \\
0,593 \\
1,244\end{array}$ \\
\hline
\end{tabular}

Berdasarkan pada Tabel 1 dapat diketahui bahwa variabel pendidikan ibu baik SD, SMP, SMA dan Sarjana memberikan pengaruh yang signifikan terhadap pemilihan sekolah lanjutan tingkat atas yaitu SMA maupun MA. Berbeda dengan pendidikan terakhir ibu setingkat SD dan SMP tidak berpengaruh signifikan terhadap pemilihan sekolah lanjutan SMK, namun siswa yang pendidikan terakhir ibunya setingkat SMA, dan sarjana yang berpengaruh terhadap pemilihan SMK. Kesignifikanan ini ditunjukkan dengan adanya nilai p-value < 0,05 . Begitu juga dengan variabel lain seperti pendidikan ayah yang meliputi SD, SMP, SMA dan sarjana juga memberikan pengaruh yang signifikan terhadap pemilihan sekolah lanjutan tingkat atas yaitu SMA maupun MA 
dan tidak memberikan pengaruh yang signifikan terhadap pilihan SMK.

Penghasilan ayah yang kurang dari $700.000,00$ per bulan juga memberikan pengaruh yang signifikan terhadap pemilihan SMA maupun MA namun tidak berpengaruh secara signifikan terhadap pemilihan SMK. Demikian juga penghasilan ibu yang kurang dari 700.000,00 dan lebih dari 2.000.000,00 juga mempunyai pengaruh signifikan terhadap pemilihan SMA maupun MA dibandingkan dengan yang lain, namun disisi lain ketiganya baik pendapatan ibu yang kurang dari 700.000,00, antara 700.000,00 sampai dengan 2.000.000,00 mapun lebih dari 2.000.000,00 memberikan pengaruh yang signifikan terhadap pemiliah SMK.

Jumlah saudara yang dimiliki siswa memberikan pengaruh yang signifikan terhadap pemilihan SMK namun tidak pada pemilihan SMA maupun MA. Siswa yang memiliki saudara sejumlah 3 orang maupun lebih mempunyai pengaruh yang signifikan terhadap pemilihan SMK. Namun tidak terjadi pada variabel jumlah tanggungan pada keluarga yang tidak berpengaruh signifikan terhadap pemilihan SMA, MA maupun SMK, kecuali siswa yang mempunyai tanggungan lebih dari 3 orang. Selain itu pekerjaaan ayah juga memberikan pengaruh yang signifikan terhadap pemilihan sekolah lanjutan tingkat atas SMA maupun MA namun tidak pada pemilihan SMK. Hanya siswa yang pekerjaan ayahnya swasta dan PNS yang mempunyai pengaruh signifikan terhadap pemilihan SMK.

Nilai rata-rata matapelajaran yang diikutkan dalam UAN mulai semester 1 sampai dengan 3 siswa yang mendapatkan diatas kisaran angka 75 lebih memberikan pengaruh yang signifikan terhadap pemilihan SMA maupun MA sehingga dapat ditentukan fungsi logit bagi masing-masing variabel yang berpengaruh signifikan diantaranya yaitu sebagai berikut:

Fungsi logit untuk siswa yang pendidikan terakhir ayahnya adalah SD atau sekolah dasar adalah :

$p_{1}(x)=1,504-4,212 S D$

$p_{2}(x)=-1,386-0,754 S D$

Fungsi logit untuk siswa yang pendidikan terakhir ayahnya SMP adalah :

$p_{1}(x)=1,504-3,701 s m p$ $p_{2}(x)=-1,386-0,811 s m p$

Fungsi logit untuk siswa yang pendidikan terakhir ayahnya SMA adalah :

$p_{1}(x)=1,504-2,306 s m a$

$p_{2}(x)=-1,386-0,256 s m a$

Fungsi logit untuk siswa yang pendidikan terakhir ayahnya sarjana adalah :

$p_{1}(x)=1,504$

$p_{2}(x)=-1,386$

Dari fungsi logit yang didapatkan seperti tertera di atas sehingga didapatkan model regresi logistik trichotomous untuk mengetahui seberapa besar peluang dari masing masing siswa untuk memilih SMA, MA maupun SMK ditinjau dari masingmasing variabel yang signifikan sebagai berikut :

Peluang bagi siswa yang pendidikan terakhir ayah SD memilih SMA adalah

$$
\begin{aligned}
\pi_{0}(x) & =\frac{1}{1+\exp P_{1}(x)+\exp P_{2}(x)} \\
& =\frac{1}{1+\exp (1,504-4,212 S D)+\exp (-1,386-0,754 S D)} \\
& =0,85
\end{aligned}
$$

Peluang bagi siswa yang pendidikan terakhir ayah SMP adalah

$$
\begin{aligned}
\pi_{0}(x) & =\frac{1}{1+\exp P_{1}(x)+\exp P_{2}(x)} \\
& =\frac{1}{1+\exp (1,504-3,701 s m p)+\exp (-1,386-0,811 s m p)} \\
& =0.82
\end{aligned}
$$

Peluang bagi siswa yang pendidikan terakhir ayah SMA adalah

$$
\begin{aligned}
\pi_{0}(x) & =\frac{1}{1+\exp P_{1}(x)+\exp P_{2}(x)} \\
& =\frac{1}{1+\exp (1,504-2,306 \text { sma })+\exp (-1,386-0,256 \text { sma })} \\
& =0,61
\end{aligned}
$$

Peluang bagi siswa yang pendidikan terakhir ayah sarjana adalah

$$
\begin{aligned}
\pi_{0}(x) & =\frac{1}{1+\exp P_{1}(x)+\exp P_{2}(x)} \\
& =\frac{1}{1+\exp (1,504)+\exp (-1,386)} \\
& =0,17
\end{aligned}
$$


Pengujian individu untuk variabel pendidikan ibu, penghasilan ibu, jumlah saudara dan pekerjaan ayah juga menunjukkan bahwa variabel-variabel tersebut mempunyai pengaruh yang signifikan terhadap pemilihan sekolah lanjutan tingkat atas. Dengan menggunakan metode perhitungan yang sama maka didapatkan nilai peluang untuk masingmasing variabel. Perhitungan peluang untuk masing-masing varaibel yang tergolong memberikan pengaruh signifikan diberikan pada Tabel 2 berikut ini :

Tabel 2 Peluang Pemilihan Sekolah Ditinjau dari Variabel yang Signifikan

\begin{tabular}{|c|c|c|c|}
\hline $\begin{array}{c}\text { Variabel } \\
\text { dan } \\
\text { Kategori }\end{array}$ & SMA & MA & SMK \\
\hline $\begin{array}{l}\text { Pendidika } \\
\text { n Ayah } \\
\text { SD } \\
\text { SMP } \\
\text { SMA } \\
\text { SARJANA }\end{array}$ & $\begin{array}{l}0,85 \\
0,82 \\
0,61 \\
0,17\end{array}$ & $\begin{array}{l}0,062 \\
0,09 \\
0,27 \\
0,78\end{array}$ & $\begin{array}{l}0,09 \\
0,09 \\
0,1176 \\
0,0043\end{array}$ \\
\hline $\begin{array}{l}\text { Pendidika } \\
\text { n Ibu } \\
\text { SD } \\
\text { SMP } \\
\text { SMA } \\
\text { SARJANA }\end{array}$ & $\begin{array}{l}0,89 \\
0,636 \\
0,704 \\
0,21\end{array}$ & $\begin{array}{l}0,056 \\
0,18 \\
0,25 \\
0,642\end{array}$ & $\begin{array}{l}0,056 \\
0,181 \\
0,045 \\
0,0143\end{array}$ \\
\hline $\begin{array}{l}\text { Penghasila } \\
\text { n Ibu } \\
<700.000 \\
700.000<\mathrm{X} \\
<2.000 .00 \\
0 \\
>2.000 .00 \\
0\end{array}$ & $\begin{array}{l}0,745 \\
0,44 \\
0,33\end{array}$ & $\begin{array}{l}0,156 \\
0,44 \\
0,67\end{array}$ & $\begin{array}{l}0,098 \\
0,11 \\
0,00000007 \\
6\end{array}$ \\
\hline $\begin{array}{l}\text { Jumlah } \\
\text { Saudara } \\
\text { Jumlah=0 } \\
\text { Jumlah=1 } \\
\text { Jumlah=2 } \\
\text { Jumlah=3 } \\
\text { Jumlah }>3\end{array}$ & $\begin{array}{l}0,61 \\
0,66 \\
0,71 \\
0,0000 \\
00009 \\
1 \\
0,72\end{array}$ & $\begin{array}{l}0,306 \\
0,193 \\
0,198 \\
0,000 \\
00001 \\
2 \\
0,27\end{array}$ & $\begin{array}{l}0,079 \\
0,142 \\
0,09 \\
0,00000000 \\
0000000002 \\
5 \\
0,00000000 \\
48\end{array}$ \\
\hline $\begin{array}{l}\text { Pekerjaan } \\
\text { Ayah } \\
\text { Lain } \\
\text { Swasta } \\
\text { Wiraswast } \\
\text { a } \\
\text { PNS }\end{array}$ & $\begin{array}{l}0,75 \\
0,74 \\
0,699 \\
0,143\end{array}$ & $\begin{array}{l}0,062 \\
0,207 \\
0,200 \\
0,714\end{array}$ & $\begin{array}{l}0,187 \\
0,051 \\
0,10 \\
0,14\end{array}$ \\
\hline
\end{tabular}

\section{Regresi Logistik Multinomial Secara Serentak}

Pada model regresi logistik secara serentak ini, variabel-variabel yang tidak signifikan pada regresi logistik multinomial yang individu tidak diikutsertakan dalam model. Variabel yang diikutkan dalam model serentak ini adalah pendidikan ayah, pendidikan ibu, penghasilan ibu, jumlah saudara, dan pekerjaan ayah. Hasil regresi logistik multinomial secara serentak. Dari model regresi logistik multinomial secara serentak didapatkan fungsi logit sebagai berikut :

$$
\begin{aligned}
p_{1}(x)=5,310- & 1,713 X_{11}-1,073 X_{12} \\
- & 0,322 X_{13}-2,989 X_{21} \\
- & 1,671 X_{22}-2,005 X_{23} \\
- & 2,418 X_{31}-0,381 X_{32} \\
+ & 0,695 X_{41}+0,137 X_{42} \\
+ & 0,388 X_{43}-18,386 X_{44} \\
- & 3,253 X_{51}-2,684 X_{52} \\
- & 4,420 X_{53} \\
p_{2}(x)=-34,726 & -1,294 X_{11}-1,650 X_{12} \\
& -0,016 X_{13}-0,925 X_{21} \\
& -0,076 X_{22}-1,817 X_{23} \\
& +18,594 X_{31}+19,930 X_{32} \\
& +19,657 X_{41}+18,811 X_{42} \\
& +17,797 X_{43}+17,149 X_{44} \\
& -1,168 X_{51}-3,095 X_{52} \\
& -1,850 X_{53}
\end{aligned}
$$

Keterangan :

$\mathrm{X}_{11}=$ pendidikan ayah SD

$\mathrm{X}_{12}=$ pendidikan ayah SMP

$\mathrm{X}_{13}=$ pendidikan ayah SMA

$\mathrm{X}_{21}=$ pendidikan ibu SD

$\mathrm{X}_{22}=$ pendidikan ibu SMP

$\mathrm{X}_{23}=$ pendidikan ibu SMA

$X_{31}=$ penghasilan $i b u<700 \mathrm{rb}$

$X_{32}=$ penghasilan ibu $700 \mathrm{rb}<x<$ $2.000 \mathrm{rb}$

$\mathrm{X}_{41}=$ Jumlah saudara 0

$\mathrm{X}_{42}=$ Jumlah saudara 1

$\mathrm{X}_{43}=$ Jumlah saudara 2

$\mathrm{X}_{44}=$ Jumlah saudara 3

$\mathrm{X}_{51}=$ Pekerjaan ayah lain - lain

$\mathrm{X}_{52}=$ Pekerjaan ayah swasta

$\mathrm{X}_{53}=$ Pekerjaan ayah wiraswasta 


\section{Uji Kesesuaian Model}

Berdasarkan pada hasil perhitungan untuk melihat apakah data empiris cocok atau tidak, diharapkan tidak ada perbedaan antara data empiris dengan model. Berdasar pada pustaka bahwa model akan dinyatakan sesuai jika signifikansi di atas 0,05 atau nilai 2 Log Likelihood kurang dari Chi Square tabel. Keterangan selanjutnya dapat dilihat dari Tabel 3

Tabel 3 Uji Kesesuaian Model

\begin{tabular}{|l|r|r|}
\hline Model & $\begin{array}{c}-2 \text { Log } \\
\text { Likelihood } \\
\left(X_{(d b, \propto)}^{2}\right)\end{array}$ & $\begin{array}{c}\text { Chi-Square } \\
\left(X^{2} \text { hitung }\right)\end{array}$ \\
\hline $\begin{array}{l}\text { Intercept } \\
\text { Only }\end{array}$ & 160,278 & \\
\hline Final & 11,091 & 149,187 \\
\hline
\end{tabular}

Tampak bahwa $\mathrm{X}^{2}{ }_{\text {hitung }} \geq \mathrm{X}^{2}{ }_{(\mathrm{v}, \propto)}$ dengan $v=g-2$. Pengambilan keputusan didasarkan pada tolak $H_{0}$ Berarti model adalah fit dan model dinyatakan sesuai dan boleh diinterpretasikan.

\section{KESIMPULAN}

Berdasarkan hasil penelitian yang telah dilakukan dapat diambil kesimpulan sebagai berikut :

Dari hasil dan pembahasan 8 variabel bebas yang mempengaruhi dalam pemilihan sekolah lanjutan tingkat atas menggunakan regresi logistik multinomial didapatkan 5 variabel bebas yang berpengaruh secara signifikan yaitu pendidikan ayah, pendidikan ibu, penghasilan ibu, jumlah saudara, dan pekerjaan ayah.

1. Hasil taksiran peluang pemilihan sekolah lanjutan ditinjau dari variabel yang signifikan siswa SMP 2, semakin rendah pendidikan terakhir yang ditempuh ayah maka semakin besar peluang siswa memilih SMA yaitu sebesar 70\%-80\%. Demikan juga dengan pendidikan terakhir ibu. Sedangkan siswa dengan penghasilan ibu yang kurang dari Rp 700.000 lebih besar peluangnya memilih SMA dibandingkan MA dan SMK. Siswa dengan jumlah saudara lebih dari 3 dan jenis pekerjaan ayah yang tidak menentu penghasilanya juga memiliki peluang paling besar untuk memilih SMA dibandingkan MA dan SMK.
Selanjutnya saran yang dapat diberikan sehubungan dengan penelitian di atas perlu banyak dilakukan penilitian lagi terhadap variabel-variabel lain yang berpengaruh terhadap pemilihan sekolah lanjutan tingkat atas sehingga dapat dioleh hasil yang lebih baik.Para siswa diharapkan mampu mengambil keputusan terbaik dalam memilih sekolah yang dituju dengan mempertimbangkan faktor-faktor yang berpengaruh. Pemerintah dianjurkan untuk menambah kuantitas dan kualitas sekolah baik SMA, MA maupun MA untuk melayani pendidikan lanjutan bagi siswa sesuai dengan pilihanya masing-masing.

\section{BIBLIOGRAPHY}

[1] Awliya, "Minat Pilihan Melanjutkan Sekolah Menengah Tingkat Atas," KOMPAS, Jakarta, 2007.

[2] A. Agresti, Categorical data analysis. John Wiley \& Sons, 2014.

[3] D. W. Hosmer Jr and S. Lemeshow, Applied logistic regression. John Wiley \& Sons, 2004. 